\title{
Somatic Symptoms in Secondary School Students and Parental Attitudes
}

\author{
İlköğretim Ikinci Kademe Öğrencilerde Somatik Belirtiler ve Anne Baba Tutumlarının Incelenmesi
}

\author{
Semra KARACA, ${ }^{1}$ Gizem ÇELEBİ, ${ }^{2}$ Zeynettin BİLEN,${ }^{3}$ Merve ÖZVATAN, ${ }^{4}$ İsmet TIMUR, ${ }^{5}$ \\ Gül ÜNSAL, ${ }^{1}$ Nevin ONAN, ${ }^{1}$ Yüksel Can ÖZ ${ }^{1}$
}

\section{SUMMARY}

Objectives: Epidemiological studies show that $5-48 \%$ of children and adolescents often experience somatic complaints. This study investigated somatic symptoms in secondary school students and the attitudes of their parents.

Methods: This descriptive study involved 699 secondary school students at three state and five private schools in Kadikoy from October 2013-February 2014. The data were collected using an information form, Child Somatization Inventory and Parent Attitude Scale and were analyzed using descriptive statistical analysis, Pearson correlation analysis and the t-test.

Results: The average age of the students was 12.93 11.06 . Of the students, $49.9 \%$ were female, and $35.3 \%$ were in private schools. A significant difference ( $t=3.53, p=.002$ ) was found based on the type of school attended with private school students seen more frequently with somatic symptoms (private $X=13.0 \pm 1.25$; state $X=10.0 \pm 9.5$ ). There were also differences according to the type of school attended in parental attitude - control/monitoring ( $t=4.43 ; p=.003$ ), and in the psychological autonomy subscale $(t=2.71, p=.040)$. Private school students' perception of their parents' attitude were more controlling/supervisory than the public school students (control/supervision; private $X=15.3 \pm 5.1$; public $X=13.8 \pm 4.0$ ) and allowing less psychological autonomy than them (private $X=26.7 \pm 4.5$; states $X=27.6 \pm 4.3$ ). Parental tolerance was significantly associated with somatic symptoms ( $t=4.695, p=.001)$, and students who perceived their parents as tolerant had more somatic symptoms ( $X=14: 31 \pm 11.86)$

Conclusion: This study shows that parental attitudes and somatic symptoms vary as to the type of school. Students had more somatic symptoms when they perceived their parents as tolerant/permitting of those somatic symptoms.

Keywords: Parents' attitudes; somatic symptoms; students.

'Department of Nursing, Psychiatrich Nursing, Marmara Universty Health Science Faculty, İstanbul

${ }^{2}$ Department of Pediatric, American Hospital, İstanbul

${ }^{3}$ Department of Internal Medicine, Koç University Hospital, İstanbul

${ }^{4}$ Department of Pediatric, Marmara Universty Pendik Training and Research Hospital, İstanbul

${ }^{5}$ Department of General Surgery, Kolan Hospital, istanbul

Correspondence (iletişim): Dr. Semra KARACA.

e-mail (e-posta): sckaraca@marmara.edu.tr

Psikiyatri Hemşireliği Dergisi 2015;6(3):114-119

Journal of Psychiatric Nursing 2015;6(3):114-119

Doi: $10.5505 /$ phd.2015.93063

Submitted (Geliş tarihi): 12.02.2015 Accepted (Kabul tarihi): 14.09.2015

\section{ÖZET}

Amaç: Epidemiyolojik çalışmalar çocuk ve ergenlerin \%5-48'inin somatik belirtileri sıklıkla deneyimlediklerini göstermektedir. Bu çalışmada ilköğretim ikinci kademe öğrencilerinde anne-baba tutumları ve somatik belirtiler arasındaki ilişkilerin incelenmesi amaçlanmıştır.

Gereç ve Yöntem: Tanımlayıcı tipteki çalışmanın örneklemini, Kadıköy'de üç devlet ve beş özel ilköğretim okulunda, Ekim 2013-Şubat 2014 tarihleri arasında ikinci kademede öğrenim gören, araştırmaya katılmayı kabul eden 699 öğrenci oluşturmuştur. Araştırma verileri Bilgi Formu, Çocuk Somatizasyon Envanteri ve Anne-Baba Tutum Ölçeği kullanılarak toplanmış, tanımlayıc istatistiksel analizler, pearson korelasyon analizi ve t-testi ile değerlendirilmiştir.

Bulgular: Öğrencilerin yaş ortalaması $12.93 \pm 1.06$ 'dır, \%49.9'u kIz, \%35.3'ü özel okula devam etmektedir. Öğrencilerin cinsiyet, ailede tek çocuk olma, eğitime devam edilen sınıf, anne-baba eğitim ve çalışma durumları ile anne-baba tutumları ve somatik belirtiler açısından anlamlı farklılık bulunmamaktadır ( $p>0.05$ ). Öğrencilerin devam ettikleri okula göre somatik belirtiler arasında anlamlı fark bulunmuştur ( $t=3.53$; $p=.002)$ ve özel okula devam eden öğrencilerde somatik belirtiler daha sık görülmektedir (özel $X=13.0 \pm 1.25$; devlet $X=10.0 \pm 9.5$ ). Öğrencilerin devam ettikleri okula göre anne-baba tutumları incelendiğinde; kontrol/denetleme ( $t=4.43 ; p=.003)$ ve psikolojik özerklik alt boyutlarında anlamlı fark bulunmuştur ( $t=2.71 ; p=.040)$, özel okullara devam eden öğrenciler anne- babalarını devlet okullarına devam eden öğrencilere göre daha fazla kontrolcü/denetleyici ve daha az psikolojik özerklik sağlayıcı olarak algılamaktadır (kontrol denetleme; özel $X=15.3 \pm 5.1$; devlet $X=13.8 \pm 4.0$ ve psikolojik özerklik özel $X=26.7 \pm 4.5$; devlet $X=27.6 \pm 4.3$ ). Ana-baba tutumlarından sadece izin verici/müsamahakar tutum ile somatik belirtiler arasında anlamlı farklılık bulunmuştur ( $t=4.695$; $p=.001)$. Ana-babalarını izin verici/ müsamahakar olarak algılayan öğrencilerde somatik belirtiler daha yüksektir $(X=14.31 \pm 11.86)$.

Sonuç: Çalışmanın sonuçlarına göre; ana-baba tutumları ve somatik belirtilerin öğrencilerin devam ettikleri okula göre farklı olduğu ve anababalarını izin verici/müsamahakar olarak algılayanlarda somatik belirtilerin yüksek olduğu belirlenmiştir.

Anahtar sözcükler: Anne-baba tutumları; somatik belirtiler; ögrenci.

\section{Introduction}

The relationship between psychological factors and disease, in other words between mind and body, has been the focus of research for centuries, leading to the creation of the field of "psychosomatic medicine." ${ }^{[1]}$ Somatization is a disorder which is characterized by bodily complaints and symptoms that cannot be explained by physical findings, and by frequent attempts to seek medical assistance. ${ }^{[2]}$

In the general population, functional medical symptoms which cannot be explained are common in children. However, somatization rarely meets the criteria of diagnosis. ${ }^{[3-5]}$ 
Bodily complaints such as headache, abdominal pain and lack of energy, which are also symptoms of somatization, are common in children and adolescents. Except for pain, the most common somatic symptoms are labored breathing, nausea, vertigo, exhaustion and fatigue. ${ }^{[1,6]}$ Of the school children, approximately $10 \%$ to $30 \%$ are affected by somatic symptoms ${ }^{[7]}$ Children and adolescents who experience somatic symptoms frequently have functional problems such as social isolation, poor peer relationships, school absences and academic difficulties, all of which harm their daily lives. In children and adolescents, somatic problems are frequently accompanied by depression and anxiety. ${ }^{[7]}$

The relevant literature reports that $90 \%$ of all somatic disorders begin before the age of 25 , and the very first symptoms are frequently seen in adolescence. ${ }^{[2]}$ However, there are few studies on somatization in childhood and adolescence in Turkey. ${ }^{[6,8]}$

Somatic disorders have a multifactor etiology. Children have a limited verbal capacity to express their feelings, and it is probable that they display their worry and distress by means of physical symptoms. ${ }^{[9]}$ Research shows that there is a significant relationship between somatization in children and adolescents and family conflicts, and the deterioration of family functionality is one of the reasons for somatization disorders. [4,10,11] Factors supporting somatization include the presence of physical diseases or disease behaviors in family members, early experiences in attracting interest and love when they were physically unwell, as well as secondary acquisitions. ${ }^{[12,13]}$ Family system theoreticians suggested that the nature of family interactive patterns plays an important role in the etiology of somatic symptoms in children, as well as their development into a chronic disorder. On the other hand, behavioral theoreticians stress that specific learning mechanisms are influential in the etiology of somatic problems. ${ }^{[1,9]}$ From the viewpoint of developmental psychopathology, somatization can be explained both by individual factors such as inadequacy in managing negative feelings and by familial risk factors, such as the prevention of emotional expression. ${ }^{[9,14]}$

Somatic symptoms may have a specific function in the family to protect and maintain the functions of the family, and sometimes prevent conflicts. A child's physical problems may serve to maintain the unity of the family or postpone conflicts, sometimes making them seem less important. ${ }^{[15]}$ For this reason, a child's somatic symptoms may be unconsciously supported by others, and children may be exposed to less stress as a result of their somatic symptoms. Schulte and Petermann's (2011) study on somatoform disorders in children and adolescents, called for further research to illuminate the relationship between familial factors and the somatic symptoms and development of somatoform disorders in children and adolescents. ${ }^{[13]}$
The literature suggests that as there are many family-related factors affecting the appearance of somatic symptoms, as well as their development into chronic disorders, this implies that there is a relationship between somatic symptoms and parental attitudes, which is the focus of this study.

\section{Tools and Methodology}

\section{The Objective and Design of the Study}

This is a descriptive and time-series study. The study aimed to analyze the relationship between parental attitudes and somatic symptoms in secondary school students.

\section{The Population and Sample of the Study}

The study was conducted with secondary school students in Kadikoy, Istanbul, between October 2013 and March 2014.

The population of the study included 16,081 secondary school students in Kadikoy. The authors calculated the sample size $(\mathrm{N}=657)$ using the formula of sample calculation with a known population, and contacted 721 students in three public and five private schools that provided consent for the study. The students were enrolled in these schools between the given dates, agreed to participate in the study and did not have any verbal communication disorders. The study was completed with 699 students who completed the data collection tools.

\section{Ethical Considerations}

The authors received consent from Marmara University's Medicine Faculty's Local Ethical Committee, as well as the written consent of the Provincial National Education Directorate for the schools in Kadikoy, Istanbul. Before proceeding with data collection, the authors informed the principals and vice-principals of the schools in question about the quality and objective of the study, and the scales included in the research. The authors collected the study data on a voluntary basis, after providing information to the students in classrooms.

\section{Data Collection Tools}

The socio-demographic data were collected using the information form, those regarding somatic symptoms were collected using the Child Somatization Inventory (CSI-24) and those regarding parental attitudes were collected using the Parental Attitude Scale (PAS).

The information form included 11 questions about the socio-demographic and familial characteristics of the participating children.

The Child Somatization Inventory-24 (CSI-24) / Child Notification is a 24-question scale which was created by Walker et al. (1991-2009). Kadioglu et al. (2012) confirmed its validity and reliability analyses in Turkish. The CSI-24 is a 5 -point Likert-type scale which includes scores from 0 
to 4 , and determines the somatic symptoms shown by the child in the past two weeks. The total score obtained from the scale is between 0 and 96 . Higher scores indicate that the somatic symptoms are frequent. In the study by Kadioglu et al. (2012), the Cronbach's alpha internal consistency coefficient was $0.91 .{ }^{[6]}$ This study found the CSI-24 Cronbach's internal consistency coefficient as 0.92 .

The Parental Attitude Scale (PAS) was created by Lamborn, Mounts, Steinberg and Dornbush. It is a 26-item scale which includes three sub-dimensions; acceptance/interest, control/supervision and psychological autonomy. ${ }^{[16]}$ The validity and reliability analyses of the scale was confirmed by Yilmaz (2000).

Those who obtained upper-intermediate scores on the acceptance/interest and control/supervision sub-dimensions demonstrated a "democratic" parental attitude. Those with scores below the average showed a "negligent" parental attitude. Participants whose scores were below average in the acceptance/interest dimension and above average in the control/supervision dimension display an "authoritarian" parental attitude. Finally, those with above average acceptance/ interest scores and below average in the control/supervision dimension demonstrate a "complaisant/permissive" parental attitude. The sub-dimensions of the scale (authoritarian, negligent, complaisant/permissive and democratic parental attitudes), which were calculated based on the mean scores, made it possible to do comparative statistical analyses. ${ }^{[16]}$ In the study by Yilmaz (2000), the Cronbach's alpha internal consistency coefficient was 0.72 in the acceptance/interest dimension; 0.76 in the control/supervision dimension and 0.82 in the psychological autonomy dimension. ${ }^{[16]}$ In this study, the Cronbach's alpha internal consistency coefficient was 0.72 in the acceptance/interest dimension; 0.76 in the control/supervision dimension; 0.78 in the psychological autonomy dimension, and 0.71 for the entire scale.

\section{Statistical Analysis}

The study evaluated the socio-demographic data, which were the independent data, based on the descriptive statistics. The authors employed the Pearson correlation analysis to evaluate the correlation between somatic symptoms and $\mathrm{pa}^{-}$ rental attitudes, both of which were the dependent variables. Somatic symptoms and parental attitudes were compared using the $t$ test.

\section{Findings}

The participating students were aged between 11 and 15 years, with an average age of $12.93 \pm 1.06$. Of the participants, $50.1 \%$ were males. Of the participating students, $35.3 \%$ were enrolled at private schools, $64.7 \%$ were enrolled at public schools, and $32.9 \%$ were in the seventh grade (Table 1).

\begin{tabular}{lcc}
\multicolumn{3}{l}{ Table 1. Sociodemographic characteristics of the students } \\
\hline Sociodemographic characteristics & & \\
\hline Age & $\mathrm{X}=12.93$ & $\mathrm{SD}=1.06$ \\
\hline & $\mathrm{n}$ & $\%$ \\
\hline Gender & & \\
$\quad$ Female & 349 & 49.9 \\
$\quad$ Male & 350 & 50.1 \\
School & & \\
$\quad$ Private School & 247 & 35.3 \\
$\quad$ Public School & 452 & 64.7 \\
Grade & & \\
$\quad$ Fifth grade & 77 & 11 \\
$\quad$ Sixth grade & 186 & 26.6 \\
$\quad$ Seventh grade & 206 & 29.5 \\
$\quad$ Eighth grade & 230 & 32.9 \\
\hline
\end{tabular}

Of the participating students, $53.2 \%$ were members of nuclear families. Of the students' mothers, $46.6 \%$ were university graduates and $51.4 \%$ were employed. Of the students' fathers, $53.4 \%$ were university graduates and $95.9 \%$ were employed (Table 2).

The most common somatic symptoms among stu-

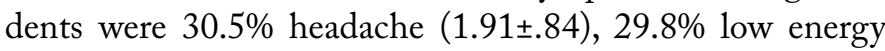

Table 2. Familial characteristics of the students

\begin{tabular}{|c|c|c|}
\hline Familial characteristics & $\mathrm{n}$ & $\%$ \\
\hline \multicolumn{3}{|c|}{$\begin{array}{l}\text { Sequence number in all the children } \\
\text { in the household }\end{array}$} \\
\hline First child & 404 & 57.8 \\
\hline Second child & 225 & 32.2 \\
\hline Third child & 54 & 7.7 \\
\hline Fourth child & 14 & 2.0 \\
\hline Fifth child & 2 & 0.3 \\
\hline \multicolumn{3}{|l|}{ The number of siblings } \\
\hline Only child & 243 & 34.8 \\
\hline Two siblings & 324 & 46.4 \\
\hline Three siblings & 102 & 14.6 \\
\hline Four siblings & 19 & 2.7 \\
\hline Five siblings & 11 & 1.6 \\
\hline \multicolumn{3}{|c|}{ Educational level of the mother } \\
\hline Illiterate & 18 & 2.6 \\
\hline Literate & 35 & 5.0 \\
\hline Secondary school & 114 & 16.3 \\
\hline High school & 206 & 29.5 \\
\hline Higher education & 326 & 46.6 \\
\hline \multicolumn{3}{|c|}{ Employment status of the mother } \\
\hline Employed & 359 & 51.4 \\
\hline Unemployed & 340 & 48.6 \\
\hline \multicolumn{3}{|c|}{ Educational level of the father } \\
\hline Illiterate & 9 & 1.3 \\
\hline Literate & 30 & 4.3 \\
\hline Secondary school & 98 & 14.0 \\
\hline High school & 189 & 27.0 \\
\hline Higher education & 373 & 53.4 \\
\hline \multicolumn{3}{|c|}{ Employment status of the father } \\
\hline Employed & 670 & 95.9 \\
\hline Unemployed & 29 & 4.1 \\
\hline
\end{tabular}


Table 3. A comparison of parental attitudes and somatic symptoms by type of school that students attend

\begin{tabular}{|c|c|c|c|}
\hline \multirow[t]{2}{*}{ School } & \multicolumn{3}{|c|}{ Parental attitudes } \\
\hline & Acceptance/interest & Control/supervision & Psychological autonomy \\
\hline & Mean \pm SD & Mean \pm SD & Mean \pm SD \\
\hline Private school $(n=247)$ & $15.6 \pm 4.5$ & $5.3 \pm 5.1$ & $26.7 \pm 4.5$ \\
\hline \multirow[t]{4}{*}{ Public school $(n=452)$} & $15.5 \pm 4.7$ & $3.8 \pm 4.0$ & $27.6 \pm 4.3$ \\
\hline & $t=0.12 / p=.541$ & $t=4.43 / p=.003$ & $\mathrm{t}=-2.71 / \mathrm{p}=.040$ \\
\hline & Somatic symptoms & & \\
\hline & Mean \pm SD & & \\
\hline \multirow{2}{*}{$\begin{array}{l}\text { Private school }(n=247) \\
\text { Public school }(n=452)\end{array}$} & $13.0 \pm 12.5$ & & \\
\hline & $\begin{array}{c}10.0 \pm 9.5 \\
t=3.53 / p=.002\end{array}$ & & \\
\hline
\end{tabular}

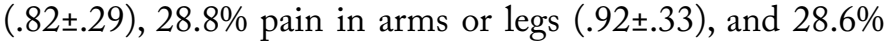
stomach ache or abdominal pain $(.82 \pm 47)$. In this study, students' mean score on somatic symptoms was $12.31 \pm 6.8$ ( $\mathrm{min}$ $1.8 \pm .29-\max 58.0 \pm 15.8)$.

Regarding the parental attitudes of the participating students; the control/supervision sub-dimension score was $27.33 \pm 4.40$; the acceptance/interest sub-dimension score was $15.54 \pm 4.69$, and the psychological autonomy sub-dimension score was $4.34 \pm 3.51$.

In terms of the socio-demographic and familial characteristics by the type of school attended, the only significant difference was between the educational levels of their parents. Of the mothers of the private school students, $74.1 \%$ were university graduates while this rate was $31.6 \%\left(X^{2}=26.31\right.$; $\mathrm{p}=0.02)$; in the public school students' mothers. Of the private school students' fathers, $84.2 \%$ were university graduates and this rate was $36.5 \%$ in the private school students' fathers $\left(X^{2}=21.41 ; p=0.03\right)$.

There was no significant difference between the students' independent variables which were student's gender, being an only child, and parents' employment status and student's grade, and the dependent variables which were parental attitudes and somatic symptoms ( $p>0.05)$. Of the independent variables of the study, the only significant difference was between somatic symptoms, parental attitudes and the student's school type.

There was a highly significant difference when comparing the prevalence of somatic symptoms by the school type of the student, where somatic symptoms were seen more frequently in private school students than in public school students. An analysis of parental attitudes by the students' school types indicated that there were significant differences in the control/ supervision and psychological autonomy sub-dimensions. Private school students perceived their parents as being more controlling/supervisory and allowing less psychological autonomy than students in public schools (Table 3).

An analysis of the correlation between parental attitudes and somatic symptoms indicated that the only intermediary, negative and significant correlation was between the psychological autonomy sub-dimension and somatic symptoms (psychological autonomy and somatic symptoms $r=-65$, $\mathrm{p}=0.01$, acceptance/interest and somatic symptoms $\mathrm{r}=-15$, $\mathrm{p}>0.05$, and control/supervision and somatic symptoms $r=-$ $19, \mathrm{p}>0.05)$.

An analysis of somatic symptoms by democratic, negligent, authoritarian and complaisant/permissive parental attitudes showed that the only significant difference was between complaisant/permissive attitude and somatic symptoms $(\mathrm{t}=4.695 ; \mathrm{p}=.001)$. Somatic symptoms were more common in the students who thought that their parents were complaisant/permissive (14.31 \pm 6.86$)$.

\section{Discussion}

The interaction of biological, environmental, psychological and social factors affects the development of somatic complaints, as well as their development into chronic disorders. Children and adolescents frequently experience somatic pains in their school years, and these pains impact upon both children and their parents. However, there are very few studies in the relevant literature that cover the school years. ${ }^{[1,4,17]}$ This study contributes to the literature with the analysis of the relationship between somatic symptoms in school age adolescents and the attitudes of their parents.

This study was conducted with children between 11 and 15 years age, and the mean score of somatic symptoms is $12.31 \pm 6.8$. Sisman et al.'s (2013) study with school children found that the mean score of somatic symptoms was $12.85 \pm 12.16,{ }^{[8]}$ which is consistent with the findings of this study. 
The most common somatic symptoms in students were headache, decrease in energy, pain in arms or legs, and stomach ache or abdominal pain. In the study by Sisman et al. (2013), the most common somatic symptoms were headache, stomach ache or abdominal pain, pain in arms or legs and decreased energy. ${ }^{[8]}$ Similarly, the study by Vila et al. (2009) found that adolescents frequently experienced headache, low energy, muscular pain, dizziness and upset stomach. ${ }^{[18]}$

The findings of this study are also consistent with other studies on somatic symptoms in children and adolescents, ${ }^{[1,6]}$ in that somatic symptoms are usually related to pain. Chronic or repetitive abdominal pain is a common symptom in children and adolescents, and usually no organic reason can be detected. ${ }^{[15,19,20]}$ Cases of pain may be created by familial or psychosocial factors. The appearance and continuance of pain may be facilitated by a variety of situations such as insufficient family support, weak family ties, and fathers with physical or psychological problems. ${ }^{[15]}$ When the study findings and literature results are analyzed jointly, it seems that pain in children and adolescents which cannot be explained medically should be investigated with a holistic approach.

The school type of the students was the only independent variable that had a significant correlation with the dependent variables (somatic symptoms and parental attitudes). In this study, somatic symptoms did not vary by gender and educational level of mothers. However, the study by Sisman et al. (2013) found that somatic symptoms were significantly more common in female students than they were in male students. Female students whose mothers were university graduates had much lower somatization scores than those whose mothers were primary, secondary and high school graduates. In male students, the education levels of mothers were not related to somatic symptoms. There was no significant difference between the education levels of fathers, economic status, family type, number of children and somatization scores. ${ }^{[8]}$ The study findings show more similarities, other than the similarities in the findings regarding gender and education levels of mothers. Therefore, the authors believe that there is a need for further studies analyzing somatic symptoms by gender and the mothers' educational levels.

When somatic symptoms were compared according to school type, it was observed that somatic symptoms were more common in private school students. This finding may be explained by the fact that both private school students and their parents have great expectations of academic achievement. According to Geralda (1999), an expectation of high academic achievement leads to the creation of high standards of behavior and achievement for children and adolescents, which in turn leads them to be anxious. Physical problems reduce high performance expectations to a secondary place which, though only temporarily, helps diminish anxiety. ${ }^{[4]} \mathrm{A}$ relevant study found that $55.93 \%$ of school children started to have pain after they had school performance problems. ${ }^{[3]}$

This study showed that the private school students perceived their parents to be more controlling/supervisory and allowing less psychological autonomy than public school students perceive their parents to be. Since parental attitude is open to many influences from the personality of parents to social and cultural characteristics, further studies are needed on this subject.

An analysis of somatic symptoms by democratic, negligent, authoritarian and complaisant/permissive parental attitudes indicated that somatic symptoms were more common in children who perceive their parents as complaisant/permissive. According to Yavuzer (1994), an over-permissive parental attitude leads to a state where the child dominates his or her parents, his or her negative behaviors are tolerated, and there is no restriction to his or her behaviors. ${ }^{[21]}$ This attitude may support somatic symptoms. Garber (1998) said that parents are inclined to be more permissive about their children's physical symptoms than psychological symptoms. They may view somatic symptoms in a better light and be more willing to accept somatic symptoms than psychological symptoms. ${ }^{[22]}$ For this reason, the authors believe that complaisant/permissive parents may be more tolerant of their children's somatic symptoms, and these children may somatize troubled situations more acutely.

\section{Study Limitations}

The sample of the study included the students in the secondary schools in Kadikoy, Istanbul. In the study, the sociodemographic characteristics other than the school type of students did not affect somatic symptoms and parental attitudes. Except for the educational levels of parents, private and public school students are homogeneous regarding their socio-demographic characteristics. The study findings cannot be generalized to students with different socio-demographic characteristics.

\section{Results and Suggestions}

The study findings showed that somatic symptoms are not very common in secondary school students. Moreover, somatic symptoms and parental attitudes did not vary by certain variables including gender, being an only child, or educational level and employment status of parents. The frequency of somatic symptoms and parental attitudes yet varied by the school type of the students (public or private). Somatic symptoms were also more common in the children who thought that their parents were complaisant/permissive. Based on the study findings, the authors suggest that further studies be conducted on children's and adolescents' somatic symptoms and related factors, with samples which have different socio-demographic characteristics, and that the results 
be incorporated into community mental health nursing and school nursing.

\section{References}

1 Siegal Lawrence J. Somatic disorders of childhood and adolescence. School Psychology Review 1990;19:174,85.

2. Özenli Y, Yoldaşcan E, Topal K, Özçürümez $G$. Türkiye'de bir eğitim fakültesinde somatizasyon bozukluğu yaygınlığı ve ilişkili risk etkenlerinin araştırılması. Anadolu Psikiyatri Dergisi 2009;10:131-6.

3. Deshpande S, Ganapathy V, Bendre N. Psychosocial morbidities in children with medically unexplained pain symptoms: A study from India. ASEAN Journal of Psychiatry 2015 (Article in press).

4. Garralda ME. Practitioner review: Assessment and management of somatisation in childhood and adolescence: a practical perspective. J Child Psychol Psychiatry 1999;40:1159-67.

5. Lavigne JV, Saps M, Bryant FB. Reexamining the Factor structure of somatization using the children's somatization inventory (CSI-24) in a community sample. J Pediatr Psychol 2012;37:914-24.

6. Kadıoğlu H, Sişman FN, Ergün A. Reliability and Validity of the Turkish Version of Children's Somatization Inventory. Asian Nurs Res (Korean Soc Nurs Sci) 2012;6:9-12.

7. Zolog TC, Jane-Ballabriga MC, Bonillo-Martin A, Canals-Sans J, et al. Somatic complaints and symptoms of anxiety and depression in a schoolbased sample of preadolescents and early adolescents. functional impairment and implications for treatment. Journal of Cognitive and Behavioral Psychotherapies 2011;11:191-208.

8. Şişman FN, Kadıoğlu H, Ergün A, Erol S. Somatization Scores of Schoolchildren and the Frequency with which Schoolchildren Visit School Health Offices with Somatic Complaints. Psikiyatri Hemşireliği Dergisi 2013;4:131-6.

9. Gledhill J, Garralda ME. Functional symptoms and somatoform disorders in children and adolescents: the role of standardised measures in assessment. Child and Adolescent Mental Health 2006;11:208-14.

10. Ayaz AB, Ayaz M, Fiş NP, Güler AS. Anxiety Level, Maternal Attachment Style and Family Functioning in Adolescents' Somatoform Disorders.
Klinik Psikiyatri 2012;15:121-8.

11. Glazebrook C, FurnessP, Tay J, Abbas K, et al. Development of a scale to assess the attitudes of paediatric staff to caring for children with medically unexplained symptoms: implications for the role of CAMHS in paediatric care. Child and Adolescent Mental Health 2009;14:104-8.

12. Kesebir S. Depresyon ve somatizasyon. Klinik Psikiyatri 2004;Ek 1:14-9.

13. Schulte IE, Petermann F. Familial risk factors for the development of somatoform symptoms and disorders in children and adolescents: a systematic review. Child Psychiatry Hum Dev 2011;42:569-83.

14. Gilleland J, Suveg C, Jacob ML, Thomassin K. Understanding the medically unexplained: emotional and familial influences on children's somatic functioning. Child Care Health Dev 2009;35:383-90.

15. Güler AS, Rodopman Arman A, Sabuncuoğlu O, Berkem M. Relationship Between Abdominal Pain in Offspring and Parental Psychopathology and Family Dynamic: A Case Report. Çocuk ve Gençlik Ruh Sağlığı Dergisi 2009;16:103-8.

16. Yılmaz A. Parenting style scale: reliabilitiy and validity. Çocuk ve Gençlik Ruh Sağlığı Dergisi 2000;7:160-72.

17. Beyer T, Furniss T. Child psychiatric symptoms in primary school : the second wave 4 years after preschool assessment. Soc Psychiatry Psychiatr Epidemiol 2007;42(9):753-8.

18. Vila M, Kramer T, Hickey N, Dattani M, et al. Assessment of somatic symptoms in British secondary school children using the Children's Somatization Inventory (CSI). J Pediatr Psychol 2009;34:989-98.

19. Wallander JL, Madan-Swain A, Klapow J, Saeed S. A randomised controlled trial of written self-disclosure for functional recurrent abdominal pain in youth. Psychol Health 2011;26:433-47.

20. Kook Heo J, Song DH. Psychosocial factors and psychiatric disorder in childhood chronic abdominal pain. Korean J Pediatr Gastroenterol Nutr 2011;14(Suppl 1):25-33.

21. Yavuzer H. Ana-baba ve çocuk. İstanbul: Remzi Kitabevi; 1994.

22. Garber J, Van Slyke DA, Walker LS. Concordance between mothers' and children's reports of somatic and emotional symptoms in patients with recurrent abdominal pain or emotional disorders. J Abnorm Child Psychol 1998;26:381-91. 